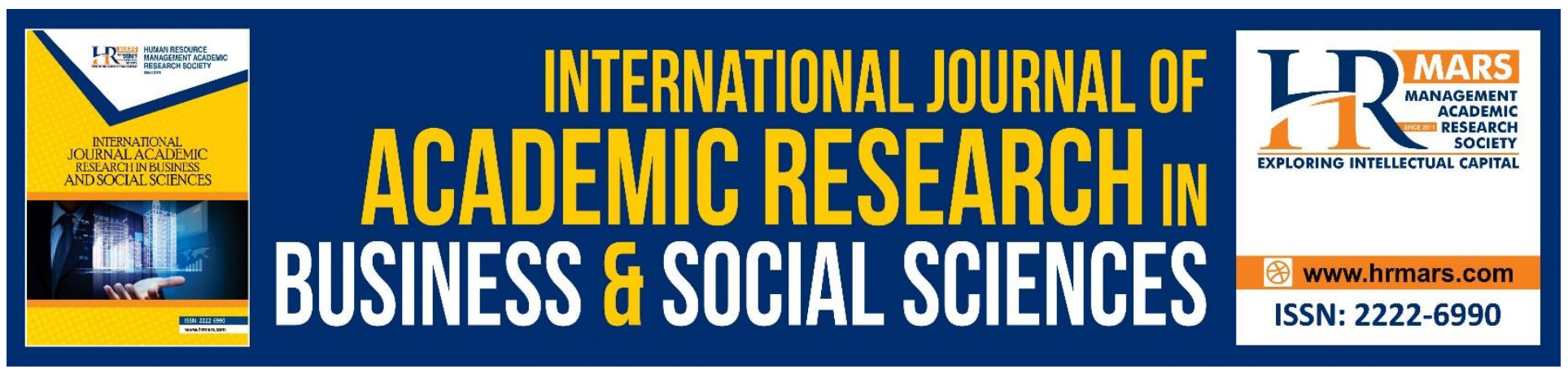

\title{
Human Resource Practitioner Professional Ability and Management System Construction, Achievement Motivation as Mediator
}

\author{
Hsien-Yu, Shun
}

To Link this Article: http://dx.doi.org/10.6007/IJARBSS/v10-i7/7397

DOI:10.6007/IJARBSS/v10-i7/7397

Received: 10 April 2020, Revised: 15 May 2020, Accepted: 19 June 2020

Published Online: 20 July 2020

In-Text Citation: (Hsien-Yu, 2020)

To Cite this Article: Hsien-Yu, S. (2020). Human Resource Practitioner Professional Ability and Management System Construction ---Achievement Motivation as Mediator. International Journal of Academic Research in Business and Social Sciences, 10(7), 72-85.

Copyright: (c) 2020 The Author(s)

Published by Human Resource Management Academic Research Society (www.hrmars.com)

This article is published under the Creative Commons Attribution (CC BY 4.0) license. Anyone may reproduce, distribute, translate and create derivative works of this article (for both commercial and non-commercial purposes), subject to full attribution to the original publication and authors. The full terms of this license may be seen

at: http://creativecommons.org/licences/by/4.0/legalcode

Vol. 10, No. 7, 2020, Pg. 72 - 85

http://hrmars.com/index.php/pages/detail/IJARBSS

JOURNAL HOMEPAGE

Full Terms \& Conditions of access and use can be found at http://hrmars.com/index.php/pages/detail/publication-ethics 


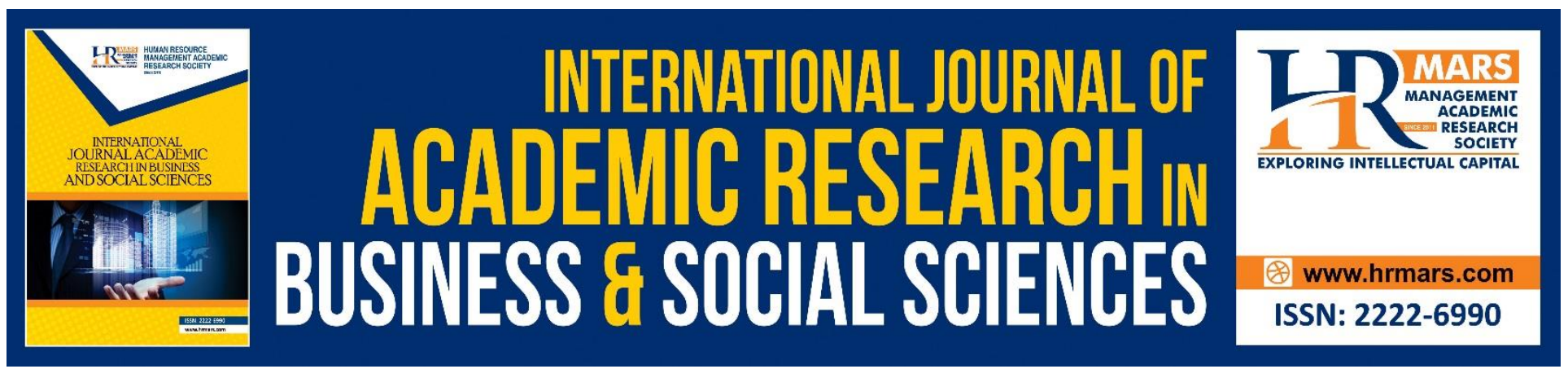

\title{
Human Resource Practitioner Professional Ability and Management System Construction ---Achievement Motivation as Mediator
}

\author{
Hsien-Yu, Shun \\ Department of Marketing, School of Economic Management, Guang Dong University of \\ Petrochemical Technology, China \\ Email: jerryhysun@hotmail.com
}

\begin{abstract}
This research explored the relationship among human resource practitioner professional ability, achievement motivation and the degree of human resource management system construction. The research focus was the human resource management practitioners in enterprises and data were collected through convenience sampling. Three hundred questionnaires were sent out, 223 valid questionnaires were returned(74.33\%). The results show that there is a significant influence between the : (1) professional ability of human resource management practitioners and the degree of human resource management system construction and (2) achievement motivation of human resource management practitioners and human resource management system construction and also that (3) achievement motivation has a partial mediating effect between professional ability and the degree of human resource management system construction.
\end{abstract}

Keywords: Achievement Motivation Human Resource Management System Mediating Effect Professional Ability.

\section{Introduction}

To succeed in a globalized economy, an organization must invest in human resources enhance skills and competences. Lawler and Mohrman (2003) asserted that human resources must rethink its functional structure, service, and planning to add value within the structure of new organizational forms and corporate policies in today's economic climate, particularly to increase the contribution of human resource departments to organizational effectiveness in the future. To effectively face new challenges, human resource departments must focus on how to add department value, how to organize, improve their effectiveness, and develop new capabilities. Wright, Gardner and Moynihan (2002) studied on the relationship between HR activities and organizational performance and profitability, and found that HR management activities (e.g., recruitment and selection, training, performance, compensation system, employee participation) and organizational commitment are related to the measurement of operational performance, operating costs, and pre-tax revenue. Some 
INTERNATIONAL JOURNAL OF ACADEMIC RESEARCH IN BUSINESS AND SOCIAL SCIENCES

Vol. 10, No. 7, July, 2020, E-ISSN: 2222-6990 @ 2020 HRMARS

studies have pointed out that human resource management systems play an important role in the relationship between organizations and employees, and the degree of system construction will affect the organizational performance. (Lin et al., 2019).

\section{Literature Review and Hypotheses}

Human Resource Practitioner Professional Ability

To achieve an organizational purpose, one of the roles of human resource management is to assist the organization to develop management systems by coordinating and communicating with internal personnel (Hall and Goodale,1986; Schuler, 1987). Constructing organizational policy and system processes is the basic work of a typical human resources department. Human resource professionals must design and implement effective human resource systems and processes, including recruitment management, training development, salary management, performance management and relevant personnel administration systems to ensure the coherency in management organization. Ulrich (1995) proposed that the structure of human resource professional function should include three main aspects: enterprise management knowledge, human resource professional functions and change management. Huselid, Jackson and Schuler (1997) proposed human resource professional goals may be associated with: human resource strategy planning, leadership, resource control, external Internet use management, enhancing human resource service quality, and risk-taking.

Ruona and Gibson (2004) suggested that since the early 1990s, the strategic role of human resources has gradually increased. Human resource personnel must cooperate with organizational strategies to design a human resources management system that can enhance organizational competitiveness and improve the value of human resource functions. Yu et al. (2012) designed an employee performance evaluation system according to organizational strategy, proposed measures to balance work and physical and mental stated of employees, and formulated a good reward system to attract outstanding colleagues to retain in an organization. To adapt to organizational change and implement it smoothly, a human resources department needs to construct a management system to fit the development of that particular organization. Therefore, the professional ability of human resource practitioners should influence human resource management system construction. Therefore, the first hypothesis of this study is:

H1: Higher professional ability of HR practitioner has a positive impact on the human resource system construction.

\section{Achievement Motivation}

Achievement motivation, a primary of personality trait, affects employees' attitude and tendency to actively solve problems within organizations or in social life. Atkinson (1957) believed that achievement motivation is an important factor in determining the level of personal ambition, effort and perseverance, and also a tendency to pursue success and avoid failure. Achievement motivation refers to an internal tendency of an individual to engage in work that is considered important or valuable, and strive to reach a more perfect level (McClelland, 1985). Chen (2007) proposed that achievement motivation has some key dimensions: preferring the challenges and difficult tasks, highly job-oriented, competitive, considering other viewpoints, and a desire to demonstrate and improve one's abilities. Achievement motivation is considered to be the result of an emotional 
conflict between the hope for success and the fear of failure. (Ricarda and Birgit, 2008). Achievement motivation is a highly personal attitude based on accomplishment. (Sharma et al. 2008).

Another very influential achievement motivation theory is the expectancy-value model of Eccles(1983). This model holds that expectancies for future success are the most important motivational determinants of achievement, whereas task values should be less important for achievement but more important for achievement choices. Halbesleben and Bowler (2007) showed that various components of achievement motivation mediate the relationship between job performance and emotional exhaustion. Lin and Li (2019) found that development-oriented HR practices are more positively related to work well-being when individual achievement motivation is high. The results guide the effective design of HR practices. Generally speaking, achievement motivation consists of a constellation of beliefs that influence patterns of achievement, including expectations and standards for performance, the value placed on learning, and self- perceptions of ability (Deci \& Ryan, 1985 ; Dweck, 2006 ; Eccles et al., 2006 ; Weiner, 2005 ). From the literature review, it was noted that high achievement motivation may depend on goals set by others. Whether the construction of a human resource management system is robust also is a function of goal setting and performance presentation of the department unit. So, hypothesis $2 a$ and hypothesis $2 b$ of this study are as follow:

H2a: Higher professional ability of an HR practitioner has a positive impact on achievement motivation.

$\mathrm{H} 2 \mathrm{~b}$ : Higher achievement motivation of an HR practitioner has a positive impact on the human resource system construction.

\section{Human Resource Management System Construction}

Zhou(2008) believed that human resource management systems should use modern scientific methods to carry out reasonable training, organization, and allocation of human resources, combined with certain material resources. Through the design of the system, people's thoughts and psychological behaviors should be properly induced, controlled, and coordinated to achieve their potential to achieve organizational goals. Liu and Shi (2005) pointed out human resource management practice refers to numerous policies and systems that affect employees' behaviors, attitudes and performance. Hsu et al. (2014) made an important classification according to five dimensions of human resource management: (1) recruitment and selection, (2) training and development, (3) performance evaluation and management, (4) salary and welfare, and (5) employee relation.

If a business does not have a complete human resource management system, daily operations and procedures cannot be carried out smoothly. If the human resource management system construction is good, it will attract talent effectively since the job seekers are often attentive to such issues. (Lievens et al., 2001). Peng (2012) suggested the problems of the human resource management systems of small businesses cannot be well established complete because they are limited cost scales to establish and integrate the system. Wang(2011) pointed out that organizations should establish a human resource evaluation system first, attracting talent then managing that talent. Suzanne (2010) 
INTERNATIONAL JOURNAL OF ACADEMIC RESEARCH IN BUSINESS AND SOCIAL SCIENCES Vol. 10, No. 7, July, 2020, E-ISSN: 2222-6990 @ 2020 HRMARS

highlighted the advantages of talent competition for large enterprises are obvious because they establish the best human resource management systems. From the above literature discussion, we documented the importance of human resource management system construction to organizational performance and personnel management. The degree of human resource management system construction also depends on the work performance of human resource departments. The performance, in turn, depends on the work ability and motivation willingness of the employees. If the professional ability is good yet achievement motivation is not, the final job performance may not achieve expected goals. Therefore, hypothesis 3 is :

H3: Achievement motivation has a mediating effect between the HR practitioner professional ability and the degree of human resource system construction.

The purpose of this research is to discuss the relationship between the professional ability of human resource practitioners and the construction of a human resource management system, and examine the achievement motivation of human resource practitioners as a mediating variable. The research framework is shown in Figure 1.

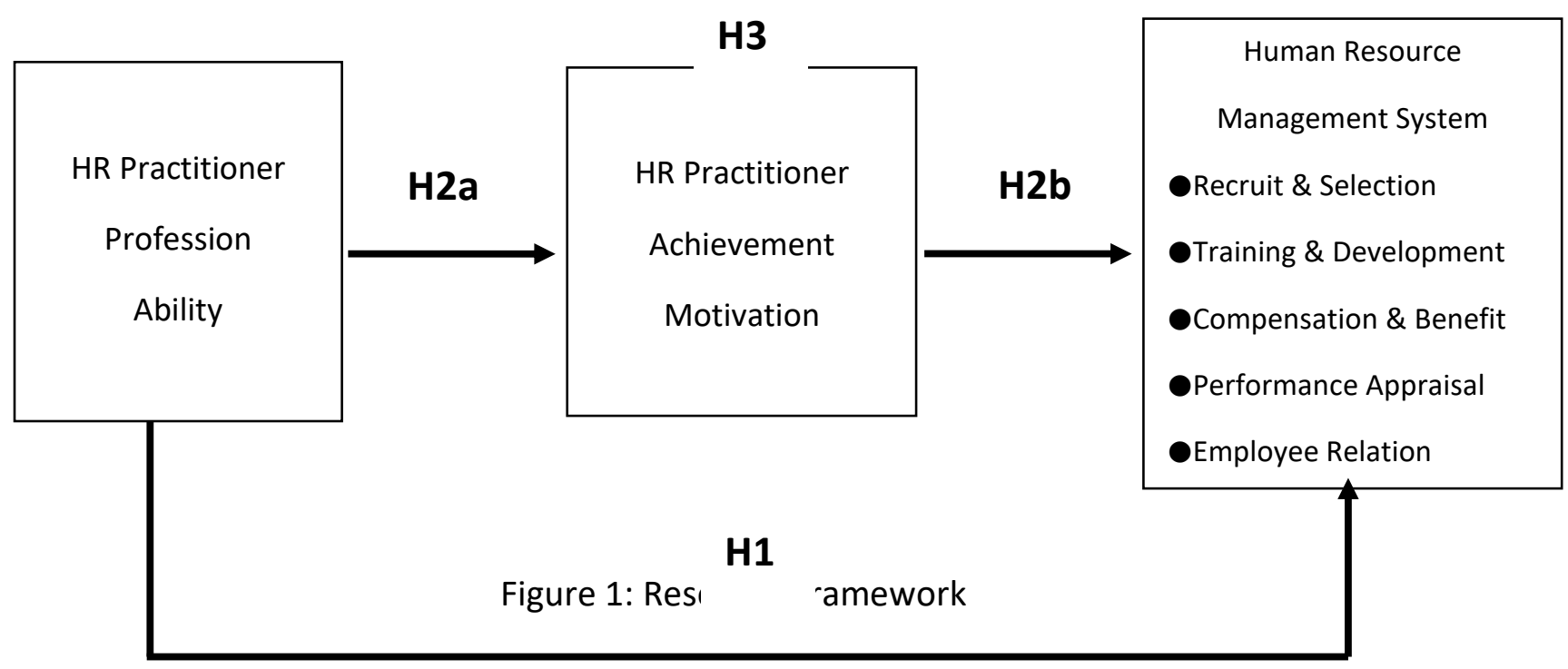

\section{Methodology}

Participants were in a human resource management training course in a management training company in Shanghai City, China, and data were collected via convenience sampling. This research used quantitative approach, specifically questionnaires. The collection period was from October 2019 to the end of January 2020. Three hundred questionnaires were sent out, 242 of which were returned (81\%). Nineteen invalid questionnaires were eliminated, leaving 223 that were valid (74.33\%).

The questionnaire design included three parts. (1) The professional ability questionnaire refers to the questions used by Huselid, Jackson \& Schuler (1997). In this study, six of the questions were used to evaluate professional abilities, including in areas such as human resource strategic planning, human resource expertise, external network resources, and service quality. Topics were measured by a 6 point Likert scale with 『6』 represent "agrees very much" and "1" represent "disagree very much". The higher the score, the higher the professional ability of the HR practitioners. (2)The achievement 
INTERNATIONAL JOURNAL OF ACADEMIC RESEARCH IN BUSINESS AND SOCIAL SCIENCES

Vol. 10, No. 7, July, 2020, E-ISSN: 2222-6990 @ 2020 HRMARS

motivation questionnaire uses the approach of Chen (2007) modified for human resource achievement motivation research. The questionnaire consists of six questions and the respondents answer based on their cognitive survey of the current work. The higher the score, the higher the achievement motivation intention of HR practitioners. (3)The human resource management system construction questionnaire design based on $\mathrm{Hsu}$ et al. (2014), including recruitment and selection(three questions), training and development (three questions), compensation and benefits(three questions), performance appraisal(four questions), and employee relation(five).

\section{Results and Discussion}

\section{Respondents' Demographic Profiles}

Demographic data include: gender, age, education level, organization position, organizational scale, and industry. The basic sample information collected from the questionnaire is shown in Table 1.

Table 1 Samples Structure Analysis

\begin{tabular}{|c|c|c|c|}
\hline Item & Characteristic & Samples & Percentage \\
\hline \multirow{2}{*}{ Gender } & Male & 64 & $28.7 \%$ \\
\hline & Female & 159 & $71.3 \%$ \\
\hline \multirow{4}{*}{ Age } & Under 30 & 32 & $14.3 \%$ \\
\hline & $31 \sim 35$ & 89 & $39.9 \%$ \\
\hline & $36 \sim 40$ & 63 & $28.3 \%$ \\
\hline & 40 Above & 39 & $17.5 \%$ \\
\hline \multirow{4}{*}{ Education } & Senior High School & 5 & $2.2 \%$ \\
\hline & College & 17 & $7.6 \%$ \\
\hline & University & 152 & $68.2 \%$ \\
\hline & Master Above & 49 & $22.0 \%$ \\
\hline \multirow{5}{*}{ Position } & Staff & 14 & $6.3 \%$ \\
\hline & Supervisor & 52 & $23.3 \%$ \\
\hline & Manager & 95 & $42.6 \%$ \\
\hline & Director & 46 & $20.6 \%$ \\
\hline & VP Above & 16 & $7.2 \%$ \\
\hline \multirow{5}{*}{ Org. Scale } & Under 50 & 17 & 7.6 \\
\hline & $51 \sim 100$ & 65 & $29.1 \%$ \\
\hline & $101 \sim 300$ & 87 & $39.0 \%$ \\
\hline & $301 \sim 500$ & 24 & $10.8 \%$ \\
\hline & 501 Above & 30 & $13.5 \%$ \\
\hline \multirow{3}{*}{ Industry } & Whole sell Service & 65 & $29.1 \%$ \\
\hline & Professional Service & 112 & $50.2 \%$ \\
\hline & Manufacture & 46 & $20.6 \%$ \\
\hline
\end{tabular}

\section{Reliability and Validity Analysis}

Reliability analysis is using internal consistency (Cronbach's Alpha) to measure the relationship of all included items. After internal consistency analysis, each item's reliability value was $\geqq 0.7$, suggesting the internal consistency reliability is acceptable (Nunnally, 1978). Human resources professional 
INTERNATIONAL JOURNAL OF ACADEMIC RESEARCH IN BUSINESS AND SOCIAL SCIENCES Vol. 10, No. 7, July, 2020, E-ISSN: 2222-6990 @ 2020 HRMARS

ability Cronbach's $\alpha$ value was 0.790 , achievement motivation was $\geqq 0.721$, the human resources system construction is $\geqq 0.7$. The results are shown in Table 2 .

Table 2 : Reliability Analysis of Questionnaire

\begin{tabular}{llcc}
\hline \multicolumn{1}{c}{ Variable Name } & \multicolumn{1}{c}{ Dimension } & Number & Cronbach's $\alpha$ \\
\hline Professional Ability & Overall questions & 5 & 0.790 \\
Achievement & Overall questions & 5 & 0.721 \\
Motivation & & & \\
& Recruitment \& Selection & 3 & 0.782 \\
Human Resource & Training \& Development & 3 & 0.763 \\
$\quad$ Practice Items & Compensation \& Benefits & 3 & 0.782 \\
& Performance Management & 4 & 0.767 \\
& Employee Relation & 5 & 0.754 \\
\hline
\end{tabular}

We used Bartlett's test of sphericity to determine the multivariate normality of the variables. The Kaiser-Meyer-Olkin (K-M-O) test evaluates sampling adequacy regarding whether the distribution of values is sufficient for conducting factor analysis (George and Mallery, 2016). According to Tabachnick and Fidell (2007), data is factorable when the KMO value is above a minimum acceptable level of 0.60 . In this research, the KMO test values were all above 0.6 , which indicated sampling adequacy and the distribution was appropriate to conduct factor analysis. Explore factor analysis was used to measure the structural validity of the scale, and the factor with an Eigen-value above one was retained. Principle component analysis, using the varimax method for the orthogonal rotation, which is then used to adjust the factor loading.

In terms of professional ability, there were originally five questions, but we deleted questions 4 and 5 because the factor loading was not above 0.5 ; after deletion, the factor loading was above 0.5 . The $\alpha$ value after deleting the questions was 0.832 , indicating the internal consistency was maintained and results are shown in Table 3.

Table 3 : Dimension、Eigen Value and Variance Explanation

\begin{tabular}{ccc}
\hline Dimension & Question & Factor \\
\hline \multirow{2}{*}{ Professional } & HRPRO1 & 0.746 \\
Ability & HRPRO2 & 0.884 \\
& HRPRO3 & 0.757 \\
\hline \multicolumn{2}{c}{ Eariance Explanation (\%) } & 1.839 \\
\hline
\end{tabular}

KMO Sampling Adequacy Testing Value : 0.634

Bartlett Test Sphericity : Chi-Suqare $=113.01$, d.f. $=3$ Sig. $=0.000$

Factor Extraction : Principal Component Analysis, PCA.

There were originally five questions about achievement motivation, but we deleted questions 1 and 4 because the factor loading did not meet the requirement to be above 0.5 . After deletion, the factor loading value reached the 0.5 requirement. The reliability $\alpha$ value after deleting the questions was 
INTERNATIONAL JOURNAL OF ACADEMIC RESEARCH IN BUSINESS AND SOCIAL SCIENCES

Vol. 10, No. 7, July, 2020, E-ISSN: 2222-6990 @ 2020 HRMARS

0.812 , indicating the internal consistency was maintained after deleting the question. The results are shown in Table 4.

Table 4 : Dimension、Eigen Value and Variance Explanation

\begin{tabular}{ccc}
\hline Dimension & Question & Factor \\
\hline Achievement & ACHIEVEMO2 & 0.883 \\
Motivation & ACHIEVEMO3 & 0.887 \\
& ACHIEVEMO5 & 0.791 \\
\multicolumn{2}{c}{ Variance Explanation (\%) } & 2.193 \\
\hline
\end{tabular}

KMO Sampling Adequacy Testing Value : 0.686

Bartlett Test Sphericity : Chi-Suqare $=247.04$, d.f. $=3$ Sig. $=0.000$

Factor Extraction : Factor Extraction : Principal Component Analysis, PCA.

The human resource management systems, there were three questions about compensation and benefits, but we deleted question 1 because the factor loading did not meet the 0.5 requirement; there were four questions about performance appraisal, and question 4 was deleted; employee relationship, question 1 was deleted. After deletion, the other factors loading value reached the 0.5 requirement. The $\alpha$ value after deleting the questions was $\geqq 0.7$, which means that good internal consistency was maintained. The results are shown in Table 5.

Table 5 : Dimension、Eigen Value and Variance Explanation

\begin{tabular}{|c|c|c|c|c|c|c|}
\hline Dimension & Question & Factor 1 & Factor 2 & Factor 3 & Factor 4 & Factor 5 \\
\hline \multirow{3}{*}{$\begin{array}{l}\text { Recruit \& } \\
\text { Selection }\end{array}$} & R\&S1 & 0.671 & & & & \\
\hline & $\mathrm{R} \& S 2$ & 0.731 & & & & \\
\hline & R\&S3 & 0.718 & & & & \\
\hline \multirow{3}{*}{$\begin{array}{c}\text { Training \& } \\
\text { Development }\end{array}$} & T\&D1 & & 0.612 & & & \\
\hline & T\&D2 & & 0.723 & & & \\
\hline & T\&D3 & & 0.807 & & & \\
\hline \multirow{2}{*}{$\begin{array}{l}\text { Compensation } \\
\text { \& Benefits }\end{array}$} & C\&B1 & & & 0.661 & & \\
\hline & C\&B2 & & & 0.832 & & \\
\hline \multirow{4}{*}{$\begin{array}{c}\text { Performance } \\
\text { Appraisal }\end{array}$} & PA1 & & & & 0.643 & \\
\hline & PA2 & & & & 0.777 & \\
\hline & PA3 & & & & 0.579 & \\
\hline & ER2 & & & & & 0.621 \\
\hline Employee & ER3 & & & & & 0.692 \\
\hline \multirow[t]{2}{*}{ Relation } & ER4 & & & & & 0.683 \\
\hline & ER5 & & & & & 0.738 \\
\hline \multicolumn{2}{|c|}{ Eigen Value } & 2.137 & 2.090 & 1.661 & 1.560 & 1.393 \\
\hline \multicolumn{2}{|c|}{ Variance Explanation (\%) } & 14.24 & 13.93 & 11.07 & 10.39 & 9.28 \\
\hline \multicolumn{2}{|c|}{$\begin{array}{c}\text { Accumulate Variance } \\
\text { Explanation (\%) }\end{array}$} & 14.24 & 27.63 & 38.70 & 49.09 & 58.37 \\
\hline \multicolumn{7}{|c|}{ KMO Sampling Adequacy Testing Value : 0.747} \\
\hline \multicolumn{7}{|c|}{ Bartlett Test Sphericity : Chi-Suqare $=611.56$, d.f. $=105$ Sig. $=0.000$} \\
\hline \multicolumn{7}{|c|}{ Factor Extraction : Principal Component Analysis, PCA. } \\
\hline
\end{tabular}


INTERNATIONAL JOURNAL OF ACADEMIC RESEARCH IN BUSINESS AND SOCIAL SCIENCES Vol. 10, No. 7, July, 2020, E-ISSN: 2222-6990 @ 2020 HRMARS

\section{Pearson Correlation Analysis}

Pearson correlation analysis was employed and Table 6 and Table 7 show the results.

Table 6 Variables Person Correlation Analysis (HRM System Construction)

\begin{tabular}{|c|c|c|c|c|c|}
\hline VAR & Mean & STD & $\begin{array}{c}\text { Professional } \\
\text { Ability }\end{array}$ & $\begin{array}{l}\text { Achievement } \\
\text { Motivation. }\end{array}$ & $\begin{array}{c}\text { HRM } \\
\text { System } \\
\text { Construction }\end{array}$ \\
\hline $\begin{array}{l}\text { Professional } \\
\text { Ability }\end{array}$ & 4.963 & 0.442 & 1 & & \\
\hline $\begin{array}{l}\text { Achievement } \\
\text { Motivation }\end{array}$ & 5.008 & 0.475 & $0.406 * *$ & 1 & \\
\hline HRM System & 4.958 & 0.376 & $0.194^{* *}$ & $0.224^{* *}$ & 1 \\
\hline
\end{tabular}

Note:,$+ \mathrm{P}<0.1 ; *, \mathrm{P}<0.05 ; * *, \mathrm{P}<0.01 ; * * *, \mathrm{P}<0.001$

Table 7 Variables Person Correlation Analysis (HRM System Each Item)

\begin{tabular}{|c|c|c|c|c|c|c|c|c|c|}
\hline VAR & Mean & STD & PRO A. & ACV M. & $R \& S$ & $T \& D$ & $C \& B$ & P.A. & E.R. \\
\hline $\begin{array}{c}\text { PRO } \\
\text { A. }\end{array}$ & 4.963 & 0.442 & 1 & & & & & & \\
\hline $\begin{array}{c}\text { ACV } \\
\text { M. }\end{array}$ & 5.008 & 0.475 & $0.406 * * *$ & 1 & & & & & \\
\hline$R \& S$ & 4.917 & 0.670 & 0.037 & 0.103 & 1 & & & & \\
\hline$T \& D$ & 4.901 & 0.616 & 0.0518 & 0.093 & $0.472 * * *$ & 1 & & & \\
\hline$C \& B$ & 4.959 & 0.549 & 0.062 & $0.204 * *$ & $0.318 * * *$ & $0.396 * *$ & 1 & & \\
\hline P.A. & 5.089 & 0.480 & $0.297 * *$ & $0.204^{* *}$ & $0.218 * *$ & $0.286^{* *}$ & $0.312 * * *$ & 1 & \\
\hline E.R. & 4.913 & 0.566 & $0.166 *$ & $0.144^{*}$ & $0.236 * *$ & $0.192 * *$ & $0.113+$ & $0.390 * * *$ & 1 \\
\hline
\end{tabular}

Note: PRO A: Professional Ability. ACVM: Achievement Motivation R\&S: Recruit \& Select T\&D:

Training \& Development C\&B: Compensation \& Benefit PA: Performance Appraisal. ER: Employee Relation.,$+ \mathrm{P}<0.1 ; *, \mathrm{P}<0.05 ; * *, \mathrm{P}<0.01 ; * * *, \mathrm{P}<0.001$

There was a significant positive correlation between the professional ability and the compensation and benefits system $\left(0.044^{* *}\right)$, performance management $\left(0.194^{* *}\right)$, and employee relationship $\left(0.094^{+}\right)$. There was a significant positive correlation between achievement motivation and four subitems: recruit and select system $\left(0.092^{+}\right)$, training and development system $\left(0.093^{+}\right)$, compensation and benefits system $\left(0.196^{* *}\right)$, and performance appraisal $(0.132 *)$.

\section{Regression Analysis}

We used linear regression analysis to analyze the influence of professional ability, human resource system construction and achievement motivation. Then, we will test whether there is a mediating effect of achievement motivation between human resource practitioner's professional ability and the human resource management system construction. The verification procedure will follow Baron and Kenny (1986) process to test the mediating effect. There are three necessary conditions for the mediating effect test: (1) Independent variable has a significant affects on dependent variable; (2) Independent variable has a significant affects on mediating variable; (3) Mediating variable has a 
INTERNATIONAL JOURNAL OF ACADEMIC RESEARCH IN BUSINESS AND SOCIAL SCIENCES Vol. 10, No. 7, July, 2020, E-ISSN: 2222-6990 @ 2020 HRMARS

significant affects on the dependent variable. If the influence of the independent variable on the dependent variable is gradually reduced after the mediator variable is added, it is called partial mediating effect; if the influence is reduced to zero, it is called complete mediating effect. The results shown as table 8 .

Table 8 Achievement Motivation Mediating Effect between the Professional Ability and HRM System Construction with Regression Analysis

\begin{tabular}{|c|c|c|c|c|c|c|c|c|}
\hline \multirow{4}{*}{ Variable Items } & \multicolumn{8}{|c|}{ Dependent Variable } \\
\hline & \multirow{2}{*}{\multicolumn{2}{|c|}{$\begin{array}{c}\begin{array}{c}\text { Achievement } \\
\text { Motivation }\end{array} \\
\text { Model } 1\end{array}$}} & \multicolumn{6}{|c|}{ HRM System Construction Degree } \\
\hline & & & \multicolumn{2}{|c|}{ Model 2} & \multicolumn{2}{|c|}{ Model 3} & \multicolumn{2}{|c|}{ Model 4} \\
\hline & $\beta$ & $T$ & $\beta$ & $T$ & $\beta$ & $T$ & $\beta$ & $T$ \\
\hline $\begin{array}{c}\text { (Independent Variable) } \\
\text { Professional Ability }\end{array}$ & 0.406 & 6.599 & 0.194 & 2.935 & --- & --- & 0.123 & 1.726 \\
\hline $\begin{array}{c}\text { (Mediator Variable) } \\
\text { Achievement Motivation }\end{array}$ & --- & --- & --- & --- & 0.224 & 3.413 & 0.174 & 2.433 \\
\hline $\mathrm{R}^{2}$ & \multicolumn{2}{|c|}{0.165} & \multicolumn{2}{|c|}{0.038} & \multicolumn{2}{|c|}{0.050} & \multicolumn{2}{|c|}{0.063} \\
\hline$\triangle R$ & \multicolumn{2}{|c|}{0.165} & \multicolumn{2}{|c|}{0.038} & \multicolumn{2}{|c|}{0.050} & \multicolumn{2}{|c|}{0.063} \\
\hline Adj. $R^{2}$ & \multicolumn{2}{|c|}{0.161} & \multicolumn{2}{|c|}{0.033} & \multicolumn{2}{|c|}{0.046} & \multicolumn{2}{|c|}{0.054} \\
\hline F Value & \multicolumn{2}{|c|}{$43.54 * * *$} & \multicolumn{2}{|c|}{$8.616 * *$} & \multicolumn{2}{|c|}{$11.645^{* * *}$} & \multicolumn{2}{|c|}{$7.363 * * *$} \\
\hline
\end{tabular}

Note:,$+ \mathrm{P}<0.1 ;{ }^{*}, \mathrm{P}<0.05 ; * *, \mathrm{P}<0.01 ; * * *, \mathrm{P}<0.001$

Professional Ability and HRM System Construction

Table 8 shows model 2 as the professional ability of a HR practitioner and the effect of human resource management system construction, $\beta$ is $0.194^{* *}(P<0.01)$, a significant positive correlation. Thus, hypothesis 1 was supported.

\section{Professional Ability and Achievement}

Table 8 shows model 1 as the professional ability of a HR practitioner and the effect of achievement, $\beta$ is $0.406^{* * *}(P<0.001)$, a significant positive correlation. Thus, hypothesis 2 a was supported.

Achievement Motivation and HRM System Construction

As shown in Table 8, model 3 includes achievement motivation as an independent variable in the regression analysis. The effect of achievement motivation on human resource management system construction, $\beta$ is $0.224^{* *}(P<0.01)$, reaching a significant positive correlation. Thus, hypothesis $2 b$ was supported.

\section{Mediating Effect Test}

As shown in Table 8, model 4 examined the mediating effect of achievement motivation between professional ability and human resource management system construction. The results in model 4, the professional ability (independent variable) $\beta$, is $0.123 * * *(P<0.001)$, achievement motivation (mediator variable) $\beta$, is $0.174^{* * *}(P<0.001)$, which has a significant positive relationship. Compare the differentiation of model $2 \beta$ value $\left(0.194^{* *}\right)$ and model $4 \beta$ value $\left(0.123^{* * *}\right)$. After model 4 add 
INTERNATIONAL JOURNAL OF ACADEMIC RESEARCH IN BUSINESS AND SOCIAL SCIENCES Vol. 10, No. 7, July, 2020, E-ISSN: 2222-6990 @ 2020 HRMARS

the achievement motivation as mediator, the professional ability affect the human resource system construction is gradually reduce. It meant the achievement motivation has a partial mediating effect between the professional ability and human resource system construction. Hypothesis 3 was supported.

Hypothesis outcomes are shown in Table 9.

Table 9 Hypothesis Outcomes

\begin{tabular}{|c|c|c|}
\hline Items & Hypothesis Content & Outcomes \\
\hline Hypothesis 1 & $\begin{array}{l}\text { Higher professional ability of HR practitioner has a } \\
\text { positive impact on the human resource system } \\
\text { construction. }\end{array}$ & Support \\
\hline Hypothesis 2a & $\begin{array}{l}\text { Higher professional ability of an HR practitioner has a } \\
\text { positive impact on achievement motivation. }\end{array}$ & Support \\
\hline Hypothesis $2 b$ & $\begin{array}{l}\text { Higher achievement motivation of an HR practitioner } \\
\text { has a positive impact on the human resource system } \\
\text { construction. }\end{array}$ & Support \\
\hline Hypothesis 3 & $\begin{array}{l}\text { Achievement motivation has a mediating effect } \\
\text { between the HR practitioner professional ability and } \\
\text { the relative degree of human resource system } \\
\text { construction. }\end{array}$ & Support \\
\hline
\end{tabular}

\section{Conclusion}

This research explored the influence of the professional ability of HRM practitioners on human resource management system construction. The main results included: (1). the higher the professional ability of human resource management practitioners, the more positive impact on human resource system construction, (2).the higher achievement motivation of human resource practitioners, the more positive impact on human resource system construction, and (3).achievement motivation had a partial mediating effect between professional ability and human resource system construction.

We showed the level of professional ability of HR practitioners has a significant positive impact on human resource system construction. Organizational performance relates to human resource management system construction. In management, enterprises improve internal process and enhancing professional abilities is one way to do so. The professional abilities of human resource practitioner include professional knowledge and skill, improve the internal customer service quality, formulate management system and policy and cross departmental coordination. In human resource practices, professional abilities can enhance through the internal and external professional course training, projects implementation plan, job rotation project design, job agent project and so on. The empirical results of this study also prove the professional ability of human resources practitioners has a significant positive impact on management system construction. Therefore, the HR department manager can carry out the above mentioned ability improvement plans from the daily work arrangement to improve the ability of personnel. Even though count in the annually department 
budget items for professional ability improvement plan and induct the external resources shall be carried out to optimize the professional ability of human resource practitioner.

Achievement motivation refers to an internal tendency of individuals to engage in work that they think is important or valuable, and strive to reach a high level. People with high achievement motivation seek solutions in their respective areas, like to set moderately difficult goals, and hope to have specific feedback to understand the quality of their work. Most high achievement motivation is performance-oriented. Due to the achievement motivation belongs to the part of deep-inside personality traits, which is difficult to be changed through external training. In business practice application, we can evaluate the achievement motivation of candidates through personality test during the recruitment and selection process. Employees with higher achievement motivation can predict that their future job performance will be better than those who with lower achievement motivation. The construction of an excellent management system can produce positive benefits for organizational performance. From the empirical results, we see that the level of achievement motivation of HR practitioners has a significant positive impact on the human resource management system construction.

Empirical analysis showed that achievement motivation does exist a partial mediating effect between professional ability and human resource system construction. This means that the level of achievement motivation will affect system construction. Even for the low professional ability group, with higher achievement motivation, the degree of influence on the system construction is higher. Therefore, how to increase the achievement motivation degree will be the critical point. In practices application, department manager could set up the specific goal and measurable performance evaluation standards that can effectively raise up individual internal satisfaction. It meant that the higher achievement motivation, the higher internal driving force for the completion of the work.

This research has some limitations. Study takes achievement motivation as the only mediating variable to explore the relationship between professional ability and human resource system construction; other behavioral motivation variables should be considered in the future. Yet, this research provides a robust framework to study relationships among human resource practitioner professional abilities, achievement motivation, and the degree of human resource management system construction.

\section{References}

Atkinson, J. W. (1957). Motivation determinants of risk-taking behaivor. Psychological Review, 64: 359-372.

Baron, R. M., \& Kenny, D. A. (1986). The moderator-mediator variable distinction in social psychological research: Conceptual, strategic, statistical considerations. Journal of Personality and Social Psychology, 51:1173-1182.

Deci, E. L., \& Ryan, R. M. (1985). Intrinsic motivation and self-determination in human behavior. New York: Plenum.

Deshpande, S. P., Golhar D. Y.(1994). HRM Practices in large and small manufacturing firms: A Comparative Study. Journal of Small Business Management, 32(2):49-56.

Dweck, C. S. (2006). Mindset: The new psychology of success. New York: Random House. 
INTERNATIONAL JOURNAL OF ACADEMIC RESEARCH IN BUSINESS AND SOCIAL SCIENCES

Vol. 10, No. 7, July, 2020, E-ISSN: 2222-6990 @ 2020 HRMARS

Eccles, J. S., Adler, T. F., Futterman, R., Goff, S. B., Kaczala, C. M., Meece, J. L. (1983). Expectancies, values, and academic behaviors. InJ.T.Spence, San Francisco: Freeman.

Eccles, J. S., Roeser, R., Vida, M., Fredricks, J. A., \& Wigfield, A. (2006). Motivational and achievement pathways through middle childhood. In L. Balter \& C. S. Tamis-LeMonda (Eds.), Child psychology: A handbook of contemporary issues (2nd ed., pp. 325-355). New York: Psychology Press.

Hall, D., \& Goodale, J. (1986). Human Resource Management. IL: Scott, Foresman and Company.

Halbesleben, J. R. B., \& Bowler, W. M. (2007). Emotional exhaustion and job performance: the mediating role of motivation. Journal of Applied Psychology, 92(1), 93-106.

Hsu, S. W., Chen, S. Y., Chang, H. Y., Chen, Y. L. (2014). A Study of Organizational Innovations, Employee's Job Satisfaction and Service Quality in The International Tourist Hotels - Human Resource Management System as a Moderator. Commerce \& Management Quarterly, Vol.15, No.4, pp.545-575.

Huselid, M. A., Jackson, S. E., \& Schuler, R. S. (1997). Technical and Strategic Human Resource Management Effectiveness as Determinants of Firm Performance. Academy of Management Journal, 40(1), pp.171-188.

Lawler, E. E., \& Mohrman, S. A. (2003). HR as a Strategic Partner: What Does It Take to Make It Happen? Human Resource Planning, 26(3), pp15-29.

Lievens, F., Decaesteker, C., Coetsier, P., \& Geirnaert, J. (2001). Organizational attractiveness for prospective applicants: A person-organization fit perspective: An International Review. Applied Psychology, 50 (1): 30-51.

Lin, C. C., Li, X. F., \& Lam, W. L. (2019). When and How Different Types of HR Practices Promote Work Well-being More Effectively: A Contingency Approach and Person-Organizational Fit Perspective. Academy of Management Proceedings, Vol.1. https://journals.aom.org/doi/10.5465/AMBPP.2019.20

Lin, C. C., Li, X. F., \& Lam, W. L. (2019). Development or maintenance? Dual-oriented human resource system, employee achievement motivation, and work well-being. Human Resource Management. DOI, https://doi.org/10.1002/hrm.21997

Liu, J. Y., Shi, K. (2005). The Influence of Human Resource Management Practices on Organizational Commitment. Journal of Ergonomic, Vol 11(4), pp21-24.

McClelland, D. C., Atkinson, J. W., Clark, R. A., \& Lowell, E. L. (1953). The achievement motive. New York: Application.

Nunnally, J. (1978). Psychometric Theory(2nd ed). New York: McGraw-Hill.

Peng, K. (2012). The SMEs problems and solution in Henan Province. Master Degree Dissertation, Henan University.

Ricarda, S., \& Brigit, S. (2008). Sex Differences in School Achievement: What Are the Roles of Personality and Achievement Motivation? European Journal of Personality. Eur. J. Pers. 22, pp. 185-209.

Ruona, W. E. A., \& Gibson, S. K. (2004). The making of twenty-first-century HR: An analysis of the convergence of HRM, HRD, and OD. Human Resource Management, 43(1), 49-66.

Schuler, R. S., \& MacMillan, I. (1984). Gaining competitive advantage through human resource practices. Human Resource Management. 23, 241-256. 
INTERNATIONAL JOURNAL OF ACADEMIC RESEARCH IN BUSINESS AND SOCIAL SCIENCES

Vol. 10, No. 7, July, 2020, E-ISSN: 2222-6990 @ 2020 HRMARS

Sharma, A., Sharp, D. M., Walker, L. G., \& Monson, J. R. T. (2008). Stress and burnout among colorectal surgeons and colorectal nurse specialists working in the National Health Service. Colorectal Disease, 10(4), 397-406.

Suzanne, R., Laszlo, S., Zsuzsanna, V. (2010). HRM in the Hungarian SME Sector. Employee Relations, 32(3), 262-280.

Tabachnick, B. G., \& Fidell, L. S. (2007). Using multivariate statistics. Needham Height, MA: Allyn \& Bacon.

Ulrich, D., Brockbank, W., Yeung, A. K., \& Lake, D. G. (1995). Human resource Competencies :An Empirical Assessment. Human resource Management, 34(4), 473-495.

Wang, L. (2011). The solutions discussion on SMEs Human Resource Management. China Trade, 10, pp.84-91.

Weiner, B. (2005). Motivation from an attributional perspective and the social psychology of perceived competence. In A. J. Elliot \& C. S. Dweck (Eds.), Handbook of competence and motivation (pp. 73-84). New York: Guilford Publications.

Wigfield, A., \& Eccles, J. S. (2000). Expectancy-value theory of achievement motivation. Contemporary Educational Psychology, 25, 68-81.

Wright, P. M., Gardner, T. M., \& Moynihan, L. M. (2002). The Impact of Human Resource Practices on Business-Unit Operating and Financial Performance. Paper presented at the University of Bath conference on HR and Firm Performance.

Yu, J., Yu, J. J., Jiang, J., Q., Liao, P. W., \& Xu, L. Q. (2012). Research on the Integration and Transformation of Human Resource Department in Different Subsidiaries-A Case Study of a Financial Holding Group. Journal of Chinese Management Review. Vol. 15, No. 2, pp.1-21.

Zhou, Y. Q. (2008). Human Resource Management: Navigation View of Cross Era. $3^{\text {rd }}$ Edition. QuanHua Press, Taipei. 